Vol 12, Issue 7, 2019

\title{
TRYPANOCIDAL, ANTI-LEISHMANIAL, AND CYTOTOXIC ACTIVITY OF MUEHLENBECKIA TAMNIFOLIA (KUNTH) MEINS (POLYGONACEAE)
}

\author{
OSCAR E. RODRÍGUEZ ${ }^{1 *}$, RUBÉN D. TORRENEGRA², LUIS M. POMBO ${ }^{3}$
}

${ }^{1}$ Faculty of Engineering, Universidad El Bosque (CHOC-IZONE), Bogotá, Colombia. ${ }^{2}$ Science Faculty, Universidad de Ciencias Aplicadas y Ambientales (UDCA), Bogotá, Colombia, (PRONAUDCA). ${ }^{3}$ School of Medicine, Fundación Universitaria Juan N. Corpas (GIFVTA), Bogotá, Colombia. Email: rodriguezoscare@unbosque.edu.co

Received: 28 April 2019, Revised and Accepted: 25 May 2019

ABSTRACT

Objective: The aim of this study was to evaluate the activity against amastigotes of Leishmania panamensis and epimastigotes of Trypanosoma cruzi (Chagas), extracts and fractions obtained from leaves and stems of Muehlenbeckia tamnifolia.

Methods: Plant material was collected during the flowering, in the town of La Calera (Cundinamarca), at a height of $2746 \mathrm{~m}$ above sea level, $4^{\circ} 43^{\prime} 11^{\prime \prime} \mathrm{N}$, $3^{\circ} 58^{\prime} 12^{\prime \prime} \mathrm{W}$. Leaves and stems were extracted with light petroleum and then with ethanol. The extracts were fractionated by column chromatography on silica gel with petrol; $\mathrm{CH}_{2} \mathrm{Cl}_{2}, \mathrm{AcOEt}$, and $\mathrm{MeOH}$. The activity against epimastigotes and cytotoxicity was evaluated by the enzymatic micromethod with MTT. The active extracts against epimastigotes and with low cytotoxicity were also evaluated in trypomastigotes and intracellular amastigotes.

Results: The dichloromethane fraction from leaves and stems of M. tamnifolia showed the highest activity against Leishmania panamensis with an $50 \%$ of the effective concentration of $0.006(\mu \mathrm{g} / \mathrm{ml})$ and a selectivity index of 4.16 . In U937 cells, six of the extracts and fractions tested showed high cytotoxicity, 50 inhibitory concentration $<50 \mu \mathrm{g} / \mathrm{ml}$.

Conclusions: The extracts obtained from leaves and stems of different polarities of $M$. tamnifolia (Kunth) Meins, revealed a moderate effect against amastigotes of L. panamensis (Leishmaniosis) (low polarity fractions) and a low effect against epimastigotes of T. cruzi (Chagas).

Keywords: Muehlenbeckia tamnifolia, Trypanocidal activity, Leishmanicidal activity, Natural products.

(C) 2019 The Authors. Published by Innovare Academic Sciences Pvt Ltd. This is an open access article under the CC BY license (http://creativecommons. org/licenses/by/4. 0/) DOI: http://dx.doi.org/10.22159/ajpcr.2019.v12i7.33790

\section{INTRODUCTION}

Leishmaniasis is zoonoses that can affect the skin, mucous membranes, or viscera, due to the parasitism of macrophages by a flagellated protozoan of the genus Leishmania, introduced to the organism by the bite of a sandfly $[1,2]$. Chagas disease is an infectious malady produced by the protozoan parasite Trypanosoma cruzi; these diseases spread throughout central, South America and are associated with poverty, poor housing conditions, and massive displacements from rural environments to cities; represents a great economic burden in Latin America among vector-borne diseases. During the past 25 years, the incidence of these diseases has been increased significantly worldwide, with the appearance of new endemic zones. For this reason, the World Health Organization currently considers them as reemerging diseases and the second cause of death among parasitic infections [3]. In addition, the treatments available are of high toxicity and high cost. For more than 20 years, the search for new antiparasitics based on natural products has been explored; however, so far, there is little knowledge about the potential of the Colombian's medicinal flora as a source of new agents against $L$. panamensis and T. cruzi [4-8].

The Polygonaceae family is characterized by the production of a large variety of secondary metabolites, many of which exhibit a potential pharmacological activity, such as anthraquinones, naphthalenes, stilbenes, steroids, glycosylated flavonoids, leucoanthocyanidins, and phenolic acids, among others [9].

The Muehlenbeckia genus is restricted to South America, Australia, and New Zealand. Species that belong to this genus, are frequently used to treat gastric ulcers; macerated leaves are used to treat kidney diseases and through infusions to relieve arthritis pain [10].
Muehlenbeckia tamnifolia (Kunth) Meins is used by Ecuadorian indigenous communities to nurse kidney diseases, in baths to relieve bone pain, or as mouthwash for toothache. It is also applied as a disinfectant and to treat purulent skin wounds [11].

In addition, Mojica et al. reported the anti-inflammatory effect of the species in animal model [12]. Previous chemical studies of the roots of M. tamnifolia showed the presence of anthraquinones such as chrysophanic acid and emodin $[13,14]$.

In the present study, the cytotoxic effect of the extracts and fractions obtained from leaves and stems of M. tamnifolia on the U937 cell line, the effectiveness against amastigotes of L. panamensis and the effectiveness against epimastigotes of T. cruzi (Chagas) were evaluated in vitro.

\section{METHODS}

\section{Plant material}

M. tamnifolia was collected during the blooming season by March 2016, in the town of La Calera (Cundinamarca), at a height of $2746 \mathrm{~m}$ above sea level, $4^{\circ} 43^{\prime} 11^{\prime \prime} \mathrm{N}, 3^{\circ} 58^{\prime} 12^{\prime \prime} \mathrm{O}$. The taxonomic identification was made by the Herbarium of the Natural Sciences Institute - National University - Colombia (COL550147)

\section{Preparation of the extract and fractions}

The dried and macerated plant material (leaves and stems) was subjected to extraction by Soxhlet with petroleum ether (bp $35-65^{\circ} \mathrm{C}$ ) until its exhaustion, it was concentrated under reduced pressure at $40^{\circ} \mathrm{C}$ to obtain the petrol extract followed by the ethanolic. The petrol extract was fractionated in column (CC), using stationary phase Silica Gel 60 (MN Kieselgel 60 0.063-0.2 mm/70-230 mesh American Society for Testing and Materials) and mobile phase mixtures of increasing 
polarity: Petrol, Petrol: $\mathrm{CH}_{2} \mathrm{Cl}_{2}(1: 1), \mathrm{CH}_{2} \mathrm{Cl}_{2}, \mathrm{CH}_{2} \mathrm{Cl}_{2}$ :AcOEt (1:1), AcOEt, AcOEt:methanol (1:1), and methanol. The same procedure was followed for the ethanolic extract.

Evaluation of anti-leishmania activity in vitro on intracellular amastigotes of $L$. panamensis

The effect of the obtained extracts from leaves and stems by Soxhlet technique on intracellular amastigotes was evaluated following the methodology described by Robledo (1998) [15]. The strain of L. panamensis (M/HOM//87/UA140) that was used was an isolated strain of a patient with localized cutaneous leishmaniasis, cryopreserved in liquid nitrogen, until its processing. To maintain the virulence of the parasite and ensure a good infection in vitro, the parasites were inoculated to golden hamster (Mesocricetus auratus) as described by Rey (1990) [16]. Periodically, the lesions were aspirated and the material obtained was cultured in a Novy, Nicolle, and McNeal medium again to obtain promastigotes. U-937 cells, maintained in suspension, were washed by centrifugation for $10 \mathrm{~min}$ at $400 \mathrm{xg}$. The supernatant was discarded and resuspended for calculating in a particle counter (Coulter). The cells were adjusted to a concentration of 100,000 cells/ml Roswell Park Memorial Institute (RPMI) medium with $10 \%$ Fetal Bovine Serum (FBS). In each well of a 24-well cell culture dish, $1 \mathrm{ml}$ of the cell suspension was distributed. To favor the adherence of the cells to the well and induce their differentiation to macrophage, $0.1 \mu \mathrm{g}$ of phorbol myristate acetate was dispersed in each well.

The cells were incubated at $37^{\circ} \mathrm{C}$ with $5 \% \mathrm{CO}_{2}$ for $48 \mathrm{~h}$ and then washed only through RPMI medium, thus removing the non-adhered cells. Adhered cells were incubated in the presence of promastigotes of $L$. panamensisin stationary growth phase and in a 25:1 ratio (parasites:cell) and incubated at $34^{\circ} \mathrm{C}$ with $5 \% \mathrm{CO}_{2}$. The cells were exposed to the parasites for $2 \mathrm{~h}$, washed in furtherance of remove the free parasites, and then reincubated for a further $24 \mathrm{~h}$, to allow the transformation of promastigotes into intracellular amastigotes. After $24 \mathrm{~h}$ of infection, the medium was completely replaced by RPMI 1640 , which contained the corresponding amount of the extract, and concentrations of extracts or fractions of M. tamnifolia obtained by Soxhlet were tested: Maximum doses evaluated for Leishmania: $0.2 \mu \mathrm{g} / \mathrm{ml}, 0.5 \mu \mathrm{g} / \mathrm{ml}, 1 \mu \mathrm{g} / \mathrm{ml}, 3.75 \mu \mathrm{g} /$ $\mathrm{ml}$, and $40 \mu \mathrm{g} / \mathrm{ml}$.

The concentration range for each extract was chosen according to the LC50. The medium was replaced every 2 days. After $96 \mathrm{~h}$ of incubation, in the presence of the extracts, the cells were washed and fixed with methanol for $20 \mathrm{~min}$ and stained with Giemsa. The infected and cultured cells in the absence of the different extracts served as control of the infection. In each well, about 200 cells were randomized, recording the number of infected and uninfected cells. The percentage of infection was calculated by dividing the number of infected cells obtained in the presence of each extract by the number of cells obtained in the absence of treatment. The results express $50 \%$ of the effective concentration $\left(\mathrm{EC}_{50}\right)$, which was calculated by the probit method [17].

\section{Trypanocidal activity evaluation}

The Colombian strain T. cruzi HA, parasites in logarithmic phase of growth were used and the test samples were incubated in 96-well plates at $27^{\circ} \mathrm{C}$ for $96 \mathrm{~h}$. After that time, MTT solution was added and after 90 min of incubation, the reading was made in an ELISA spectrophotometer; the data were analyzed by the probit method [17].

Concentrations of extracts or fractions of I - $333 \mu \mathrm{g} / \mathrm{ml}$, II $-250 \mu \mathrm{g} / \mathrm{ml}$, III - $500 \mu \mathrm{g} / \mathrm{ml}$, IV $-100 \mu \mathrm{g} / \mathrm{ml}$, and V - $200 \mu \mathrm{g} / \mathrm{ml}$ were tested. Those extracts or fractions with a percentage of inhibition $>50 \%$ at $100.0 \mu \mathrm{g} / \mathrm{ml}$ or an $\mathrm{LC}_{50}<50.0 \mu \mathrm{g} / \mathrm{ml}$ are considered active.

\section{Toxicity evaluation on $\mathrm{U}-937$ cells}

The evaluation of the cytotoxic activity was carried out on human promonocytic cells of the U-937 line, according to (3-(4,5-dimethylthiazol2-il)-2,5-diphenyltetrazolium bromide) (MTT) proposed by Sereno (1997) [18]. U-937 cells were maintained in culture as cells in suspension in RPMI 1640 medium (Gibco BRL, Grand Island, NY), enriched with 10\% inactive fetal bovine serum $(\mathrm{SBF})$ at $37^{\circ} \mathrm{C}$ and $5 \% \mathrm{CO}_{2}$ at a concentration of $3 \times 10^{5} \mathrm{cells} / \mathrm{ml}$, and changing medium every 2 days. On the day of the assay, the cells were washed by centrifuging at $400 \times \mathrm{g}$ for $10 \mathrm{~min}$.

The supernatant was discarded and the cell button was resuspended in RPMI 1640 medium supplemented with $10 \%$ SBF. The cells were counted and adjusted to a concentration of $1 \times 10^{6}$ cells $/ \mathrm{ml}$ of RPMI with $10 \%$ SBF. In each well of a 96 -plate, $100 \mu \mathrm{l}$ of cells were dispensed. Then, $100 \mu \mathrm{l}$ of a solution of the different extracts of M. tamnifolia dissolved in DMSO, in a final concentration range of 3-100 $\mu \mathrm{g} / \mathrm{ml}$, were added. The cells were incubated at $37^{\circ} \mathrm{C}$ with $5 \% \mathrm{CO}_{2}$ for $96 \mathrm{~h}$, changing the medium each $48 \mathrm{~h}$.

After $96 \mathrm{~h}, 10 \mu \mathrm{l}$ of MTT $(10 \mu \mathrm{g} / \mathrm{ml})$ was added to each well and the plate was incubated for $3 \mathrm{~h}$. The enzymatic reaction was stopped by the addition of $100 \mu \mathrm{l}$ of $50 \%$ isopropanol and $10 \%$ sodium dodecyl sulfate. The wells were incubated an additional $30 \mathrm{~min}$ at room temperature and the optical density was read at $570 \mathrm{~nm}$, using an ELISA reader (BioRad). The cells cultured in the absence of treatment, but maintained under the same conditions, served as control of the assay.

\section{Analysis of data}

The results were expressed as the 50 inhibitory concentration $\left(\mathrm{IC}_{50}\right)$, which corresponds to the concentration at which $50 \%$ of cell death occurs. Cytotoxicity was categorized into the following three levels: High cytotoxicity, for extracts with $\mathrm{IC}_{50}<50 \mu \mathrm{g} / \mathrm{ml}$; mildly cytotoxic, for extracts with $\mathrm{IC}_{50}$ between 51 and $100 \mu \mathrm{g} / \mathrm{ml}$; and slightly cytotoxic extracts, for those with IC 50 above $100 \mu \mathrm{g} / \mathrm{ml}$. The selectivity index (SI) was obtained by the quotient between the $\mathrm{IC}_{50}$ in U937 cells and the $\mathrm{CI}_{50}$ in the parasites studied. Extracts or fractions with selectivity indexes $\geq 3$ are considered selective.

\section{RESULTS}

The antiparasitic activity against T. cruzi and L. panamensis was evaluated, as well as the cytotoxic activity on U937 cells of nine extracts and fractions obtained from leaves and stems of M. tamnifolia. On U937 cells, six of the extracts and fractions tested showed high cytotoxicity, $\mathrm{IC}_{50}<50 \mu \mathrm{g} / \mathrm{ml}$ (66.6\%). The remaining three showed mild cytotoxicity, $\mathrm{IC}_{50}>100 \mu \mathrm{g} / \mathrm{ml}$ (33.3\%). The most cytotoxic fraction was dichloromethane $\left(\mathrm{CH}_{2} \mathrm{Cl}_{2}\right)$ with $\mathrm{IC}_{50}$ of $0.025 \mu \mathrm{g} / \mathrm{ml}$.

Only the dichloromethane fraction $\left(\mathrm{CH}_{2} \mathrm{Cl}_{2}\right)$ was selective $(11.11 \%)$, $\mathrm{SI}>3$, on amastigotes of $L$. panamensis with a percentage of inhibition of $43.40 \%$ at the highest concentration evaluated $(40 \mu \mathrm{g} / \mathrm{ml})$. This fraction was inactive against T. cruzi epimastigotes.

The light petroleum extract showed the highest percentage inhibition against T. cruzi epimastigotes (97\%); however, its cytotoxicity is very high and its SI is very low.

On the other hand, the fraction of ethyl acetate (AcOEt) had a percentage of $88 \%$ inhibition compared to L. panamensis, $\mathrm{EC}_{50}=27.1$ $\mu \mathrm{g} / \mathrm{ml}$ and $\mathrm{SI}=1.70$ and a percentage inhibition of $56 \%$ against T. cruzi, $\mathrm{EC}_{50}>200 \mu \mathrm{g} / \mathrm{ml}$ and $\mathrm{SI}<0.23$ (Table 1).

\section{DISCUSSION}

Leishmaniasis and Chagas disease are parasitic infections that have been developing resistance to frequently used drugs. The toxicity and high costs of the available drugs make these diseases difficult to manage. Therefore, the search for alternative sources of treatment for the aforementioned diseases becomes a priority.

In this search, research on plant extracts and their derivatives has become very important. The foregoing is evidenced, for example, in studies conducted in Colombia with Annona muricata against L. braziliensis and L. panamensis, where it was shown that the activity was greater compared to that of meglumine antimonate 
Table 1: Effect of extracts and fractions of $M$. tamnifolia on the U937 cell line and antiparasitic activity

\begin{tabular}{|c|c|c|c|c|c|c|c|c|}
\hline \multicolumn{2}{|c|}{$\begin{array}{l}\text { Fractions and extracts of leaves and } \\
\text { stems of } M \text {. tamnifolia }\end{array}$} & \multirow{2}{*}{$\begin{array}{l}\begin{array}{l}\mathrm{U} 937 \\
\text { cytotoxicity }\end{array} \\
\mathrm{IC}_{50}(\mu \mathrm{g} / \mathrm{ml})\end{array}$} & \multicolumn{3}{|c|}{$\begin{array}{l}\text { Effectiveness against amastigotes of } \\
\text { L. panamensis }\end{array}$} & \multicolumn{3}{|c|}{$\begin{array}{l}\text { Effectiveness against epimastigotes of } \\
\text { T. cruzi }\end{array}$} \\
\hline $\begin{array}{l}\text { Extract or } \\
\text { fraction }\end{array}$ & Type & & Inhibition (\%) & $\begin{array}{l}\mathrm{EC}_{50} \\
(\mu \mathrm{g} / \mathrm{ml})\end{array}$ & $\begin{array}{l}\text { Selectivity } \\
\text { index }\end{array}$ & $\begin{array}{l}\mathrm{EC}_{50} \\
(\mu \mathrm{g} / \mathrm{ml})\end{array}$ & Inhibition (\%) & $\begin{array}{l}\text { Selectivity } \\
\text { index }\end{array}$ \\
\hline Much-H1 & Light petroleum extract & 1.40 & 28.40 & 0.70 & 2.00 & $>200$ & 97.00 & $<0.007$ \\
\hline Much-H1.1 & Light petroleum: $\mathrm{CH}_{2} \mathrm{Cl}_{2}$ & 468.20 & 0.00 & 302 & 1.55 & $>200$ & 50,8 & $<2.34$ \\
\hline Much-H1.2 & Fraction* $\mathrm{CH}_{2} \mathrm{Cl}_{2}$ & 0.025 & 43.40 & 0.006 & 4.16 & $>200$ & 0.00 & $<0,000125$ \\
\hline Much-H1.4 & Fraction* AcOEt & 46.10 & 88 & 27.10 & 1.70 & $>200$ & 56.00 & $<0.23$ \\
\hline Much-H1.5 & Fraction $\mathrm{MeOH}$ & 1.52 & 47.20 & 1.10 & 1.38 & $>200$ & 0.00 & $<0.0076$ \\
\hline Much-H2 & Extract EtOH & 123.10 & 36.80 & 123.10 & 1.00 & $>200$ & 0.00 & $<0.625$ \\
\hline Much-H2.1 & Fraction light petroleum & 4.90 & 22.40 & 2.20 & 2.22 & $>200$ & 20.30 & $<0.0245$ \\
\hline Much-H2.2 & Fraction $\mathrm{CH}_{2} \mathrm{Cl}_{2}$ & 8.10 & 0.00 & 5.40 & 1.50 & $>200$ & 4.90 & $<0.04$ \\
\hline
\end{tabular}

*The most active fractions are highlighted in bold. The dichloromethane fraction showed the highest activity against L. panamensis with an $\mathrm{EC}_{50}$ of 0.006 ( $\mu \mathrm{g} / \mathrm{ml}_{\text {) }}$ and an SI of 4.16. $\mathrm{IC}_{50}: 50$ inhibitory concentration, $\mathrm{EC}_{50}: 50 \%$ of the effective concentration, L. panamensis: Leishmania panamensis, T. cruzi: Trypanosoma cruzi,

M. tamnifolia: Muehlenbeckia tamnifolia

(glucantime). Some of the active compounds isolated from plants against leishmaniasis belong mainly to the following chemical groups: Alkaloids, triterpenes, sesquiterpenes, monoterpenes, diterpenes, and flavonoids [19].

Some phytochemical studies of the species M. tamnifolia have reported the presence of triterpenoids such as lupeol and $\beta$-sitosterol $[13,20]$. Das et al. found that lupeol has significant anti-Leishmania activity with $\mathrm{IC}_{50}$ values of 65 and $15 \mu \mathrm{g} / \mathrm{ml}$ compared to promastigote and amastigote, respectively [21]. Other triterpenic compounds, such as betulinic acid, have anti-leishmanial activity, activity that can be related to the inhibition of topoisomerase [22,23].

The presence of this type of compounds could explain the promising anti-Leishmania activity of the dichloromethane fraction.

\section{CONCLUSIONS}

The extracts obtained from leaves and stems of different polarities of $M$. tamnifolia (Kunth) Meins show a moderate activity against amastigotes of L. panamensis (Leishmaniosis) (low polarity fractions) and a low activity against epimastigotes of T. cruzi (Chagas). This leishmanicidal activity could be explained by the presence of triterpenetype bioactive compounds such as lupeol. The fraction dichloromethane $\left(\mathrm{CH}_{2} \mathrm{Cl}_{2}\right)$ showed the most cytotoxic activity with an $\mathrm{IC}_{50}$ of $0.025 \mu \mathrm{g} / \mathrm{ml}$ on U937 cells. More studies should be carried out to determine the structure-activity relationship.

\section{ACKNOWLEDGMENTS}

We express our thanks to Dr. Fernando Echeverry of the University of Antioquia and his research group for the support for the development of this investigation.

\section{AUTHORS' CONTRIBUTIONS}

All authors contributed equally in the design of the study, data collection, data analysis, and in the writing of the manuscript.

\section{CONFLICTS OF INTEREST}

The authors have no conflicts of interest.

\section{REFERENCES}

1. Arévalo Y, Robledo S, Muñoz DL, Granados-Falla D, Cuca LE, Delgado G. Evaluación in vitro de la actividad de aceites esenciales de plantas colombianas sobre Leishmania braziliensis. Rev Colomb Cienc Quím Farm 2009;38:131-41.

2. Desjeux P. Leishmaniasis: Situación actual y nuevas perspectivas. Comp Immunol Microbiol Infect Dis 2004;27:305-18.

3. WHO. Control of the Leishmaniases: Report of a Meeting of the WHO
Expert Committee on the Control of Leishmaniases. Geneva: WHO Technical Report Series; No. 949; 2010. p. 186.

4. Valencia L, Muñoz D, Robledo S, Echeverri F, Arango G, Vélez I, et al. Actividad tripanocida y citotóxica de extractos de plantas colombianas. Biomédica 2011;31:552-9.

5. Guhl F, Lazdins-Held J. Grupo de Trabajo Científico Sobre la Enfermedad de Chagas. Geneva: Special Programme for Research and Training in Tropical Diseases; 2007. p. 5-31.

6. Phillipson JD, Wright CW. Medicinal plants against protozoal diseases. Trans R Soc Trop Med Hyg 1991;85:155-65.

7. Kayser O, Kinderlen AF, Croft SL. Natural products as antiparasitic drugs. Parasitol Res 2003;90:55-62.

8. Weniger B, Robledo S, Arango GJ, Deharo E, Aragón R, Muñoz V, et al. Antiprotozoal activities of Colombian plants. J Ethnopharmacol 2001;78:193-200.

9. Vasas A, Orbán-Gyapai O, Hohmann J. The genus Rumex: Revisión de usos tradicionales, fitoquímica y farmacología. J Ethnopharmacol 2015; $175: 198-228$.

10. Burnie G, Forrester S, Greig D. Botánica Guía Ilustrada de Plantas: Más de 10000 Especies de la A la Z y Cómo Cultivarlas. Hong Kong: Konemann; 2006. p. 1020.

11. De la Torre L, Navarrete H, Muriel MP, Macia MJ, Balslev H. Enciclopedia de las Plantas Útiles del Ecuador; Herbario QCA and Herbario AAU: Quito, Ecuador: Aarhus; 2008. p. 947.

12. Mojica BJ, Torrenegra RD, Pombo LM, Cadavid V, Rodríguez OE. Antiinflammatory effect of the hydroalcoholic extract of Muehlenbeckia tamnifolia (Kunth) meins leaves in a rat paw model. Pharmacologyonline 2017;3:13-22.

13. Torres-Naranjo M, Suárez A, Gilardoni G, Cartuche L, Flores P, Morocho V, et al. Chemical constituents of Muehlenbeckia tamnifolia (Kunth) meisn (Polygonaceae) and its in vitro $\alpha$-amilase and $\alpha$-glucosidase inhibitory activities. Molecules 2016;21:1-10.

14. Pablo M, Lilia G, Judith H, Carmela G. Anthraquinone pigments in Muehlenbeckia tamnifolia and Muehlenbeckia vulcanica. Politecnica 1973;3:111-22

15. Robledo SM, Valencia AZ, Saravia NG. Sensitivity to glucantime of Leishmania viannia isolated from patients prior to treatment. J Parasitol 1999;85:360-6.

16. Rey JA, Travi BL, Valencia AZ, Saravia NG. Infectivity of the subspecies of the Leishmania braziliensis complex in vivo and in vitro. Am J Trop Med Hyg 1990;43:623-31.

17. Finney DJ. Probity Analysis. London: Cambridge Press Londres; 1964. p. 318.

18. Sereno D, Lemesre JL. Use of an enzymatic micromethod to quantify amastigote stage of Leishmania amazonensis in vitro. Parasitol Res 1997;83:401-3.

19. Rocha LG, Almeida JR, Macêdo RO, Barbosa-Filho JM. A review of natural products with antileishmanial activity. Phytomedicine 2005; $12: 514-35$.

20. Rodríguez OE, Torrrenegra RD, Beltrán AS, Matulevich JA, Castrillon WF. Metabolitos de baja polaridad en hojas de Muehlenbeckia tamnifolia (Kunth) meisn. Rev Tecnol 2014;13:95-108.

21. Das A, Jawed JJ, Das MC, Sandhu P, Manash C, Das PS, et al. Antileishmanial and immunomodulatory activities of lupeol, a triterpene compound isolated from Sterculia villosa. Int J Antimicrob 
Agents 2017;50:512-22.

22. Kar N, Ghosh S, Kumari L, Chakraborty S, Bera T. Search for new antileishmanial chemotherapeutics. Int $\mathrm{J}$ Pharm Pharm Sci 2018;10:46-2. Available from: https://innovareacademics.in/ journals/index.php/ijpps/article/view/20859. [Last accessed on 2019 May 22].
23. Kaur R, Kaur J, Kaur S, Joshi J. Evaluation of the antileishmanial efficacy of medicinal plant Chenopodium album Linn. Against experimental visceral leishmaniasis. Int $\mathrm{J}$ Pharm Pharm Sci 2016;8:227-31. Available from: https://www.innovareacademics. in/journals/index.php/ijpps/article/view/11726. [Last accessed on 2019 May 22] 